\title{
New England Village
}

\section{G. M. Candler}

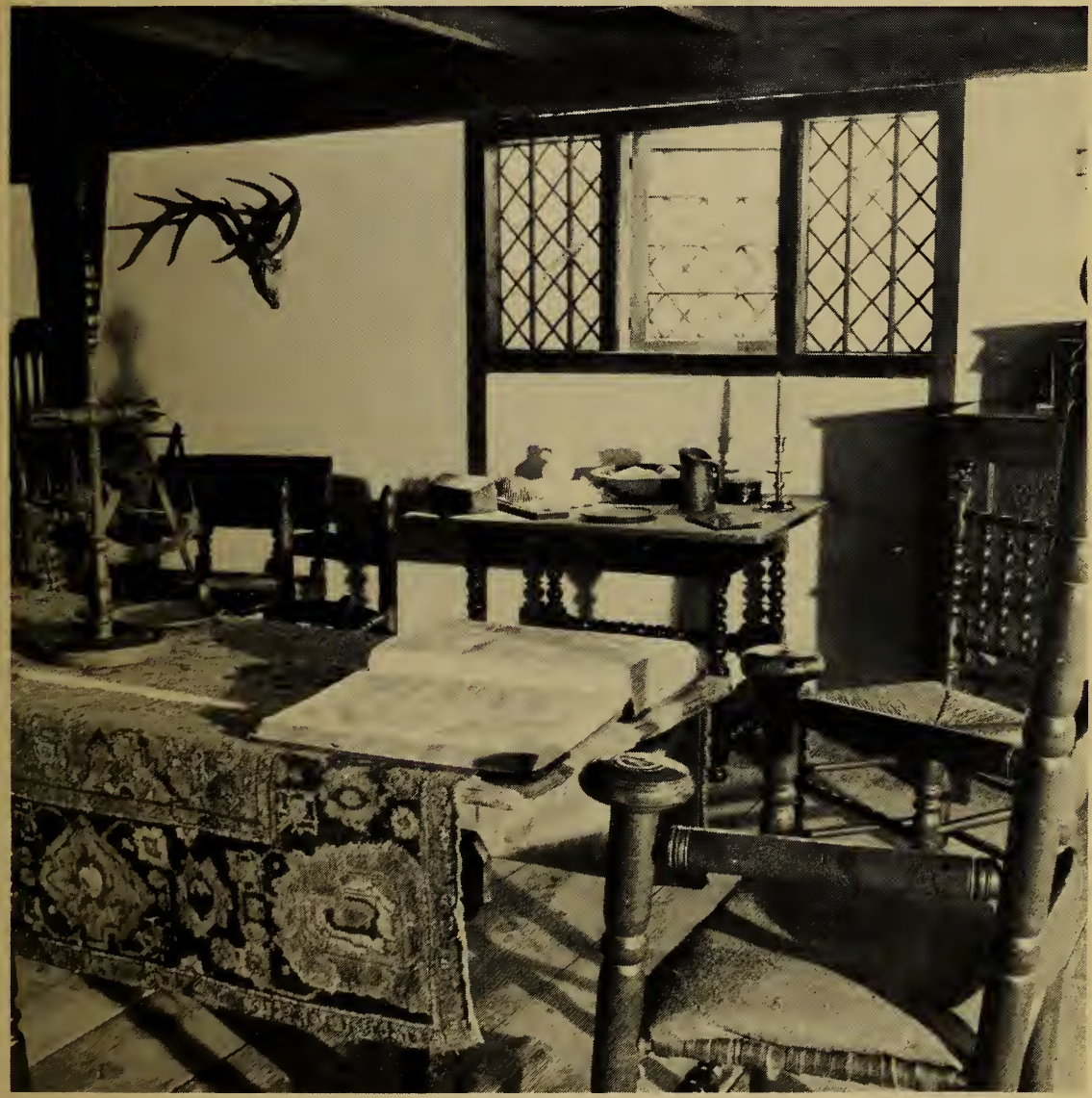

Aublished by the
Claverton Manor-Bath·Somerset





\title{
New England Village
}

Some aspects of life in a New England settlement during the seventeenth century

\author{
G. M. CANDLER \\ Director of Education, The American Museum in Britain
}

Illustrations by S. M. Candler
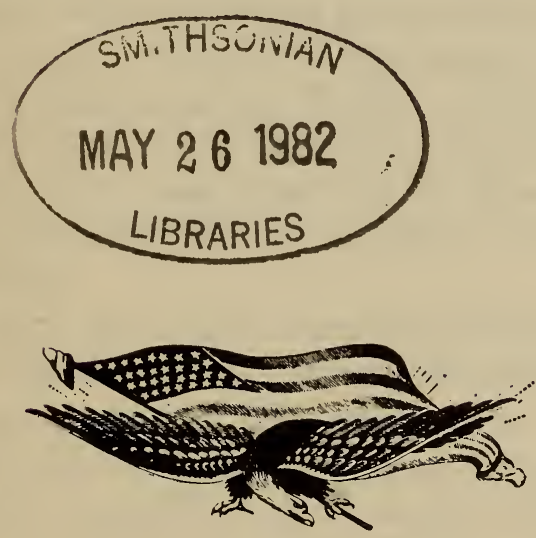

THE AMERICAN MUSEUM IN BRITAIN 



\section{Introduction}

The first permanent English settlement on the east coast of North America was made early in the seventeenth century. By the end of the century settlements were scattered along more than a thousand miles of coast from Maine to South Carolina. In the south the climate made possible the development of plantations, and Virginia and Maryland soon prospered on the growing of tobacco. The Middle Colonies of Pennsylvania and New York were far more varied in their trade and agriculture. Of all the colonies, however, those to the north were made in an area most suited to English settlement, as the name New England implies. Massachusetts, Connecticut, New Hampshire, and Rhode Island had all been established by the end of the century. But there was to be little contact for a long time between the different colonies. Many rivers cut into the long irregular coastline. While providing good harbours and inland routes, they also made for small and often isolated settlements. By 1690 the population of the English colonies in North America numbered just over two hundred thousand. Though many merchants of the time considered the West Indies to be of far greater importance, the future growth of the American colonies was assured.

The coastal area was rich in natural resources. Boundless forests provided game - deer, turkey, wild geese, and great flocks of pigeons; the rivers and coastal waters teemed with fish; and in time other resources, such as iron, were discovered. The climate made it possible to grow many of the grain and vegetable crops known in England. Maize, or Indian corn, was bought at first from the natives, but soon became a staple crop in New England. 


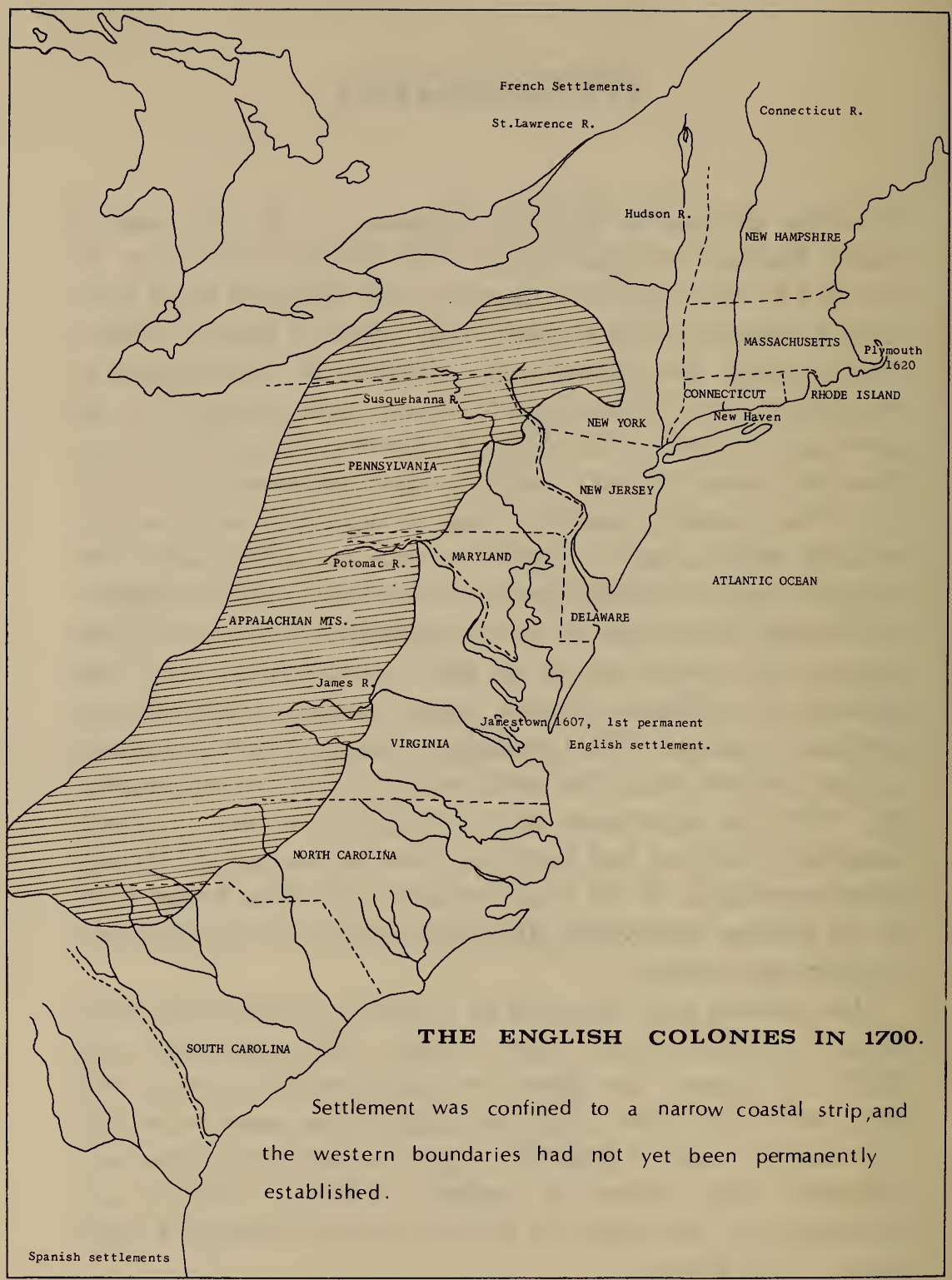




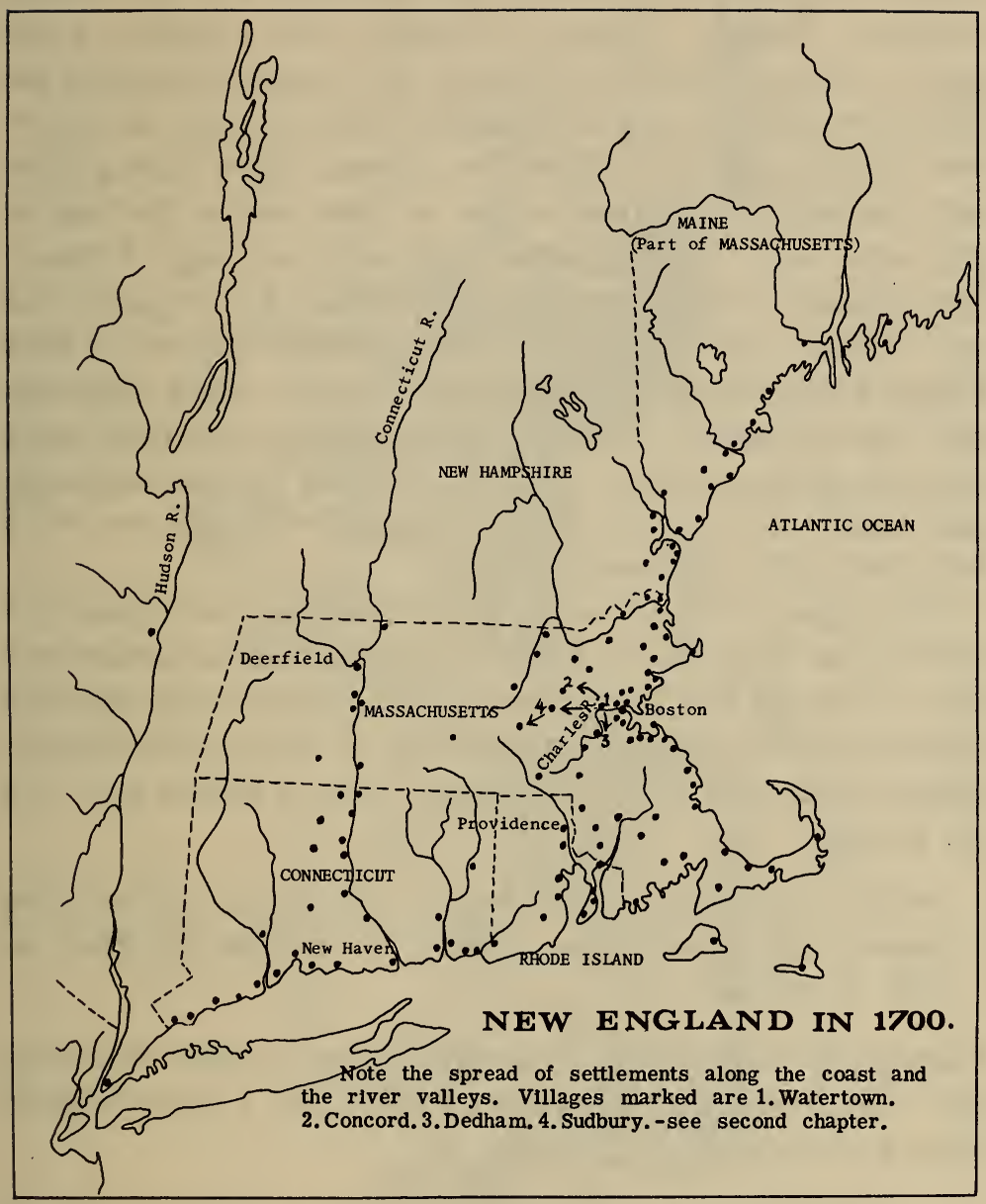


Merchants who supported colonizing ventures saw their purpose as being to provide raw materials for the Mother Country. Thomas Weston of Bristol, for example, wrote angrily to the Plymouth Colony in 1621 complaining that the Mayflower had returned to England without a cargo. He understood little of the difficulties the colonists faced during those early months. Yet within a year of their arrival the men of Plymouth were loading cedar clapboards and kegs of beaver pelts aboard another merchant ship bound for England. Fur and lumber were to be two of the principal exports of New England throughout the seventeenth century. More important still was the fishing industry. Small boats put out from many ports along the northern coast, and headed for the Newfoundland Banks and the great shoals of codfish. The fish was salted and dried, then exported to Europe.

Throughout this period of early settlement the majority of colonists in New England lived in small, scattered settlements away from the few large towns. Their diaries make frequent mention of the problems of living on or close to the frontier. Indian attack was a constant danger, and a hidden one - for the Indians

'would not come to open battle with them, but fire their houses, kill their cattle, and lie in ambush for them as they go abroad'.

Disease often struck with devastating effect, as John Winthrop, the first governor of the Massachusetts Bay Colony, showed when he wrote in August 1642,

'A plantation was begun the last year at Delaware Bay by those of New Haven, and some 20 families were transported thither, but this summer there fell such sickness and mortality among them as dissolved the plantation.' 


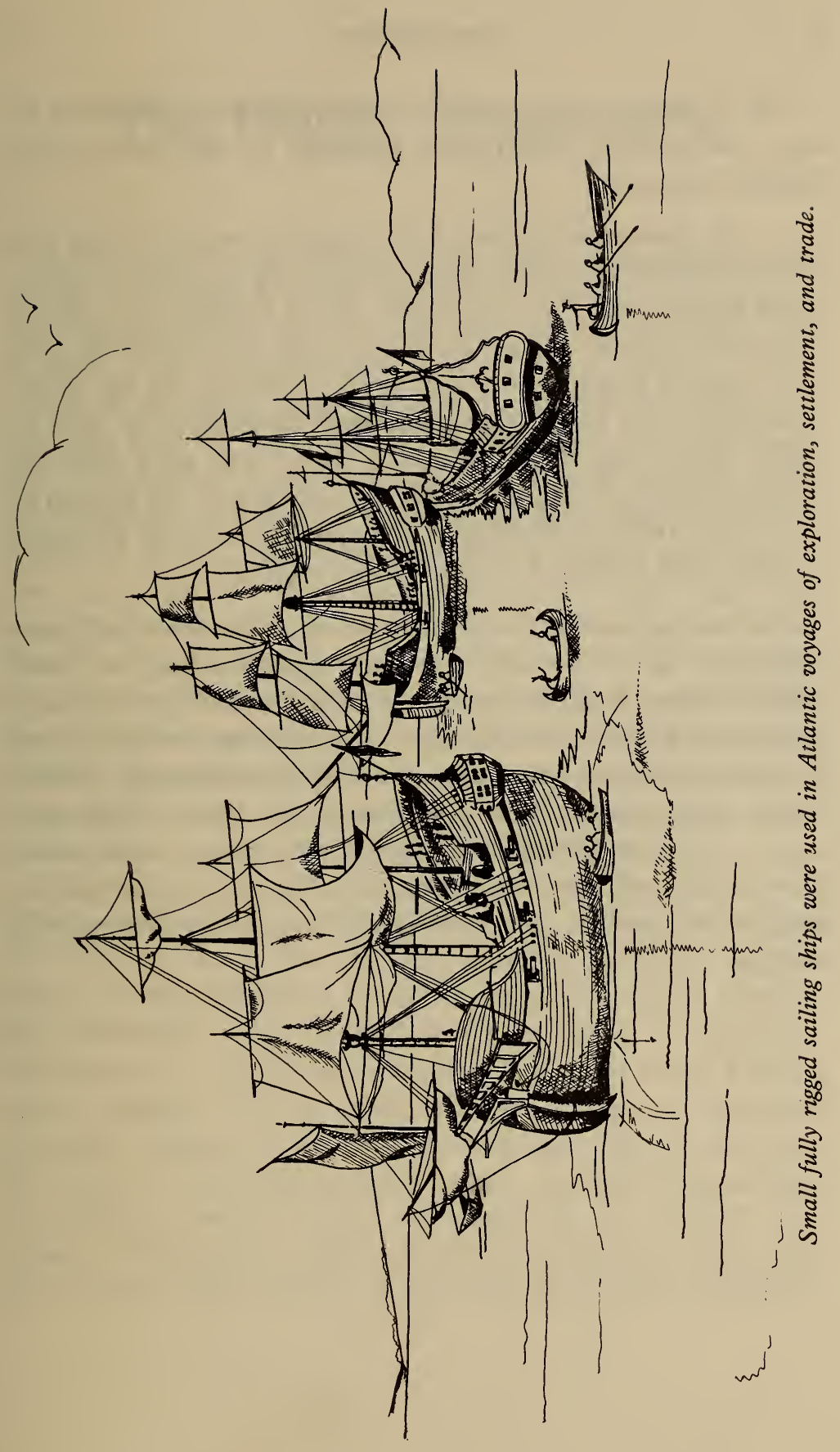


The following year several natural elements combined to leave the settlers inadequately provided for the severe New England winter:

'The immediate cause of this scarcity were the cold and wet summer, especially in the time of the first harvest; also, the pigeons came in such flocks, (above 10,000 in one flock,) that beat down, and eat up a very great quantity of all sorts of English grain; much corn spent in setting out the ships, ketches, etc.; lastly, there was such abundance of mice in the barns, that devoured much there. The mice also did much spoil in orchards, eating off the bark at the bottom of the fruit trees in the time of the snow, so as never had been known the like spoil in any former winter.'

Despite these difficulties many small settlements had been established in the coastal area and inland along the river valleys of New England by the end of the seventeenth century. To the south the Dutch had been ousted from New York, and no other European settlements seemed strong enough, at least for the time being, to pose a serious threat. Many of the most urgent problems facing the original settlements, such as the shortage of food, had been overcome. Yet the way of life for most people was not so very different from those first years of struggle. 


\section{The Village Community}

The term 'town' was applied to any New England settlement which had obtained certain 'liberties' or powers. It might be the chief town of Boston, with an estimated population in 1690 of some 7,000; on the other hand it could refer to a small village of twenty or thirty households. Boston was the largest and most thriving town, not only in New England but throughout the colonies. Trade with the West Indies, with the other colonies, and with Britain brought much wealth to the merchants of Boston. Its narrow streets and lanes - once said to have been laid out by a meandering cow - were filled with noise and bustle. Many trades were carried on in the rows of houses with their high-pitched roofs and gables. Yet the majority of New Englanders lived far from such scenes. Theirs was an agricultural and rural way of life. Travel between the villages was difficult since the roads were poor, and there were many rivers and streams to cross. Most people rarely ventured far beyond the borders of the township.

The system of land-holding in these country districts was similar to that of the English manor, but without the control of a lord of the manor. As the population increased a small group, perhaps members of one congregation, would apply to the governing body for permission to plant a settlement. Watertown, on the Charles River a few miles above Boston, is one example. By the mid-1630's this was one of the most populous villages in the Masachusetts Bay Colony. No more free grants of land were being made, and all the good land was either in use or staked out ready for use. In 1635 two groups of Watertown people applied to the General Court and were granted land, the one at Concord, the other at Dedham. 


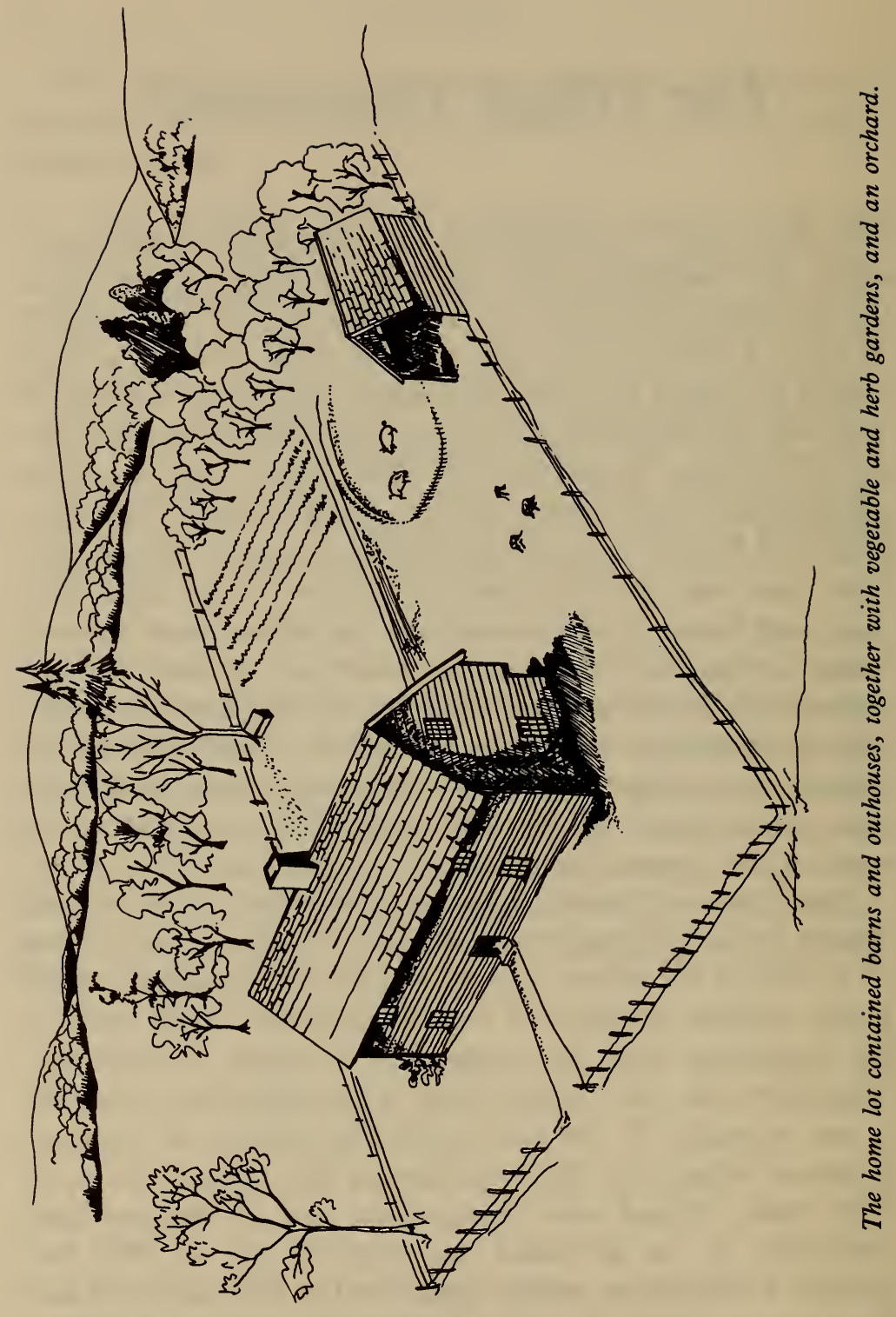




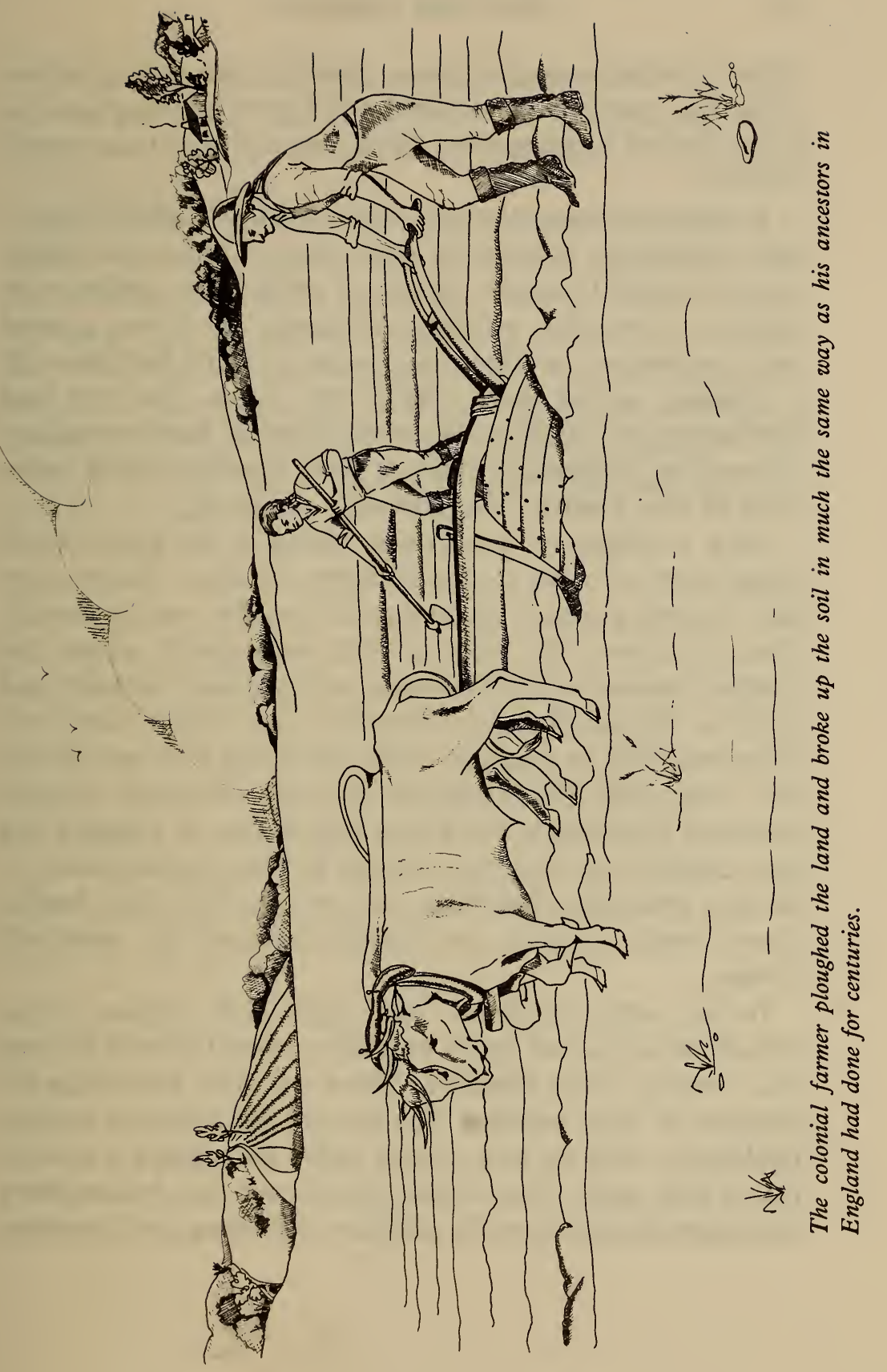


Three years later another group, pleading 'straitness of accommodation, and want of meadow', were given a land grant in a broad plain of meadow grass below Concord soon to be named Sudbury.

A generation later the sons of the original Sudbury settlers were themselves anxious to obtain land. Led by the deputy to the General Council, a group of twelve men applied to be allowed to establish another settlement. The Court granted their application provided some twenty or thirty families, with a minister, settled there within three years. The first land distribution was made in the new village of Marlborough, to the west of Sudbury, in 1660. In these ways the inland settlement of New England was gradually extended.

Once a village was established leaders of the group would assign plots of land to the different families. Houses were built around a central common, while nearby was the church. Home lots were the areas of land immediately around the dwelling houses and outbuildings, and contained orchards and gardens. Beyond these the meadows and pasture land were sometimes held in common, while the arable land was divided into strips held by individuals. But the movement towards enclosing land which had begun long before in England had been carried over into the colonies. In New England many of the first settlements had been made by men from East Anglia, where land enclosure had largely replaced the open-field system.

Indian corn and wheat were staple New England crops, though oats, rye, and barley were also grown. Colonial farming was, however, very primitive. There was little knowledge for example of crop rotation. The plough was a clumsy wooden implement, with an iron cutting edge, and needed a team of two or four oxen. Once turned, the soil was then broken down with mattocks and hoes. In addition to clearing land, breaking 
up the soil, and tending the crops for long months before the harvest, the farmer had to look after his livestock, the cattle, sheep, and pigs. Throughout the year his days were long ones, stretching from dawn to dusk.

Land at least was plentiful in most areas, and could often be had for the taking, provided the farmer was prepared to clear and make it productive. From the earliest times, however, he had to turn his hand to many tasks in order to survive in the wilderness. He had to learn to hunt and fish, to build a house, to make furniture and many other household items, to defend his home from attack. All of this was in addition to his work on the land. One of his first and most important tasks was to make a home. 


\section{Houses}

The climate and the materials available determined the type of house built in New England in the seventeenth century. An even stronger influence, however, was the English origin of the settlements. The most typical example was the simple and practical frame house, a type which had been built for centuries in England and which continued to be built into the seventeenth century, particularly in East Anglia.

The frame house replaced the earliest shelters erected as temporary homes in the colonies. These had taken many forms, including tents made from sail-cloth, and 'holes within the ground', as Captain John Smith had described the dugouts, with their roofs of poles and bark, at Jamestown. Perhaps most interesting of all were the 'English wigwams' known to have been used at Plymouth. These tunnel-like structures were made with a framework of poles, and covered with bark or skins. They were often improved by the addition of fireplaces and crude wooden chimneys. In their basic form they provide another example of the way in which contact with the Indian was sometimes to the advantage of the European.

These temporary shelters began to be replaced as soon as the settlers had the opportunity to build more substantial homes. For the most part they disappeared within a few years. They were replaced by houses with timber frames of hewn oak posts and beams. Walls were sometimes made of brick, but more often of wattle and daub, which was a kind of basketwork of branches set into the frame and daubed with clay or plaster on both sides. In England similar houses often had both frame and wall filling exposed. In New England clapboarding was used. Horizontal overlapping boards were nailed to the frame to 


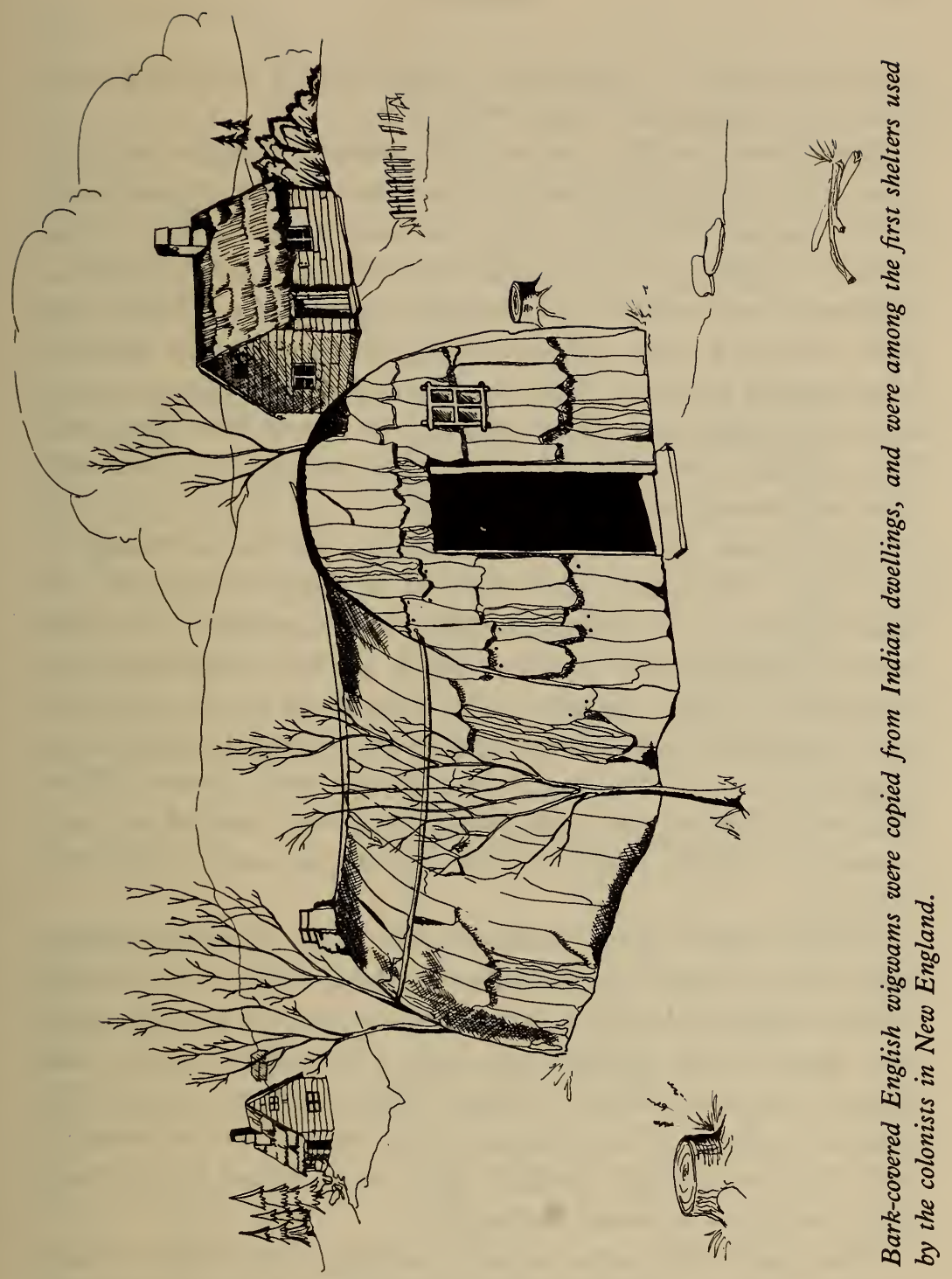


cover the whole of the exterior walls, thereby providing extra protection against the harsh winters.

Roofs were usually covered with wooden shingles made of pine. They replaced the earlier thatched roofs which were such a fire hazard. Windows were few and small owing to the scarcity of glass, much of which was brought from England. Attempts were made to manufacture glass in the colonies, but they met with little success during the seventeenth century. The window glass was made in diamond-shaped panes, and set into lead, which was often imported in sheets from England. Some windows were fixed, while others were of the casement type and swung outward on a hinge.

One curious feature of these houses was the overhang in the front. This again was a copy of an English idea, but the exact purpose is a matter of conjecture. Certainly it did not provide cover against Indian attack as has sometimes been suggested. It may possibly have originated in the need for more space at the first-floor level in the cramped streets of an English town. In this case its use in the open spaces of New England villages was unnecessary, and was carried on as a matter of custom until it died out in the early eighteenth century.

Houses were usually small at this time, size being determined not so much by the timber available as the way in which it was worked. Most jobs were done by hand. The main posts and beams were squared off with a broadaxe, boards and planks were sawn with a two-man 'whip-saw', and some of the interior surfaces of the timbers were smoothed down with an adze. Not surprisingly builders often chose to use fairly young trees, which were easier to handle.

The plan of the house varied according to the needs of each family. Certain well-recognized types soon began to emerge, however. To begin with there was a simple one-room plan. Here 


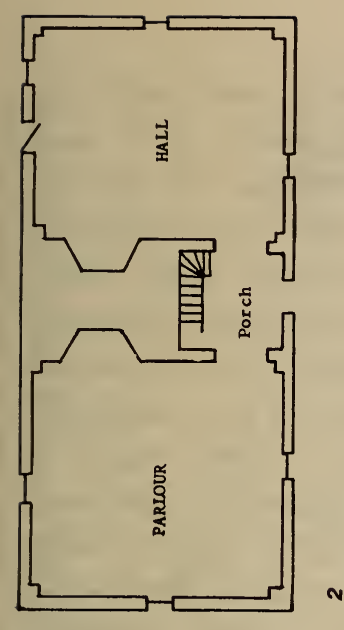

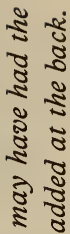

\%

ริ

帘

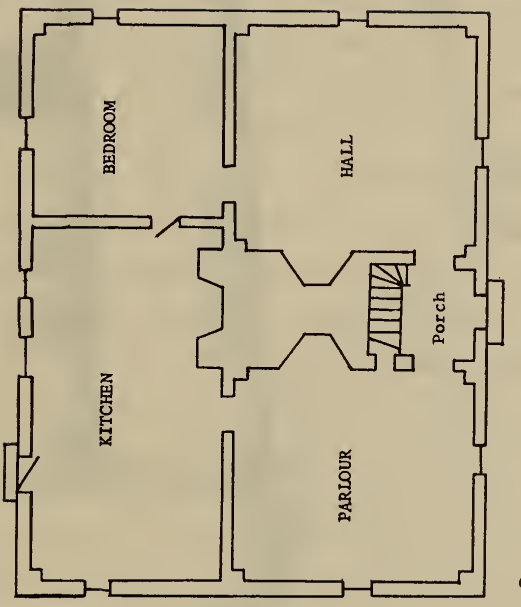

ช

ईิ

क⿱

赵

$\nabla$.

, $\stackrel{\text { ล }}{3}$

हี

ริ

ㅇำ

ปั ฐี

ะ

ह

ए

$\sim 2$

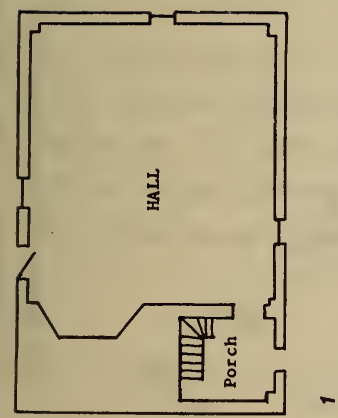

$\ddot{2}$

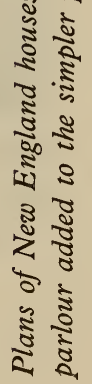




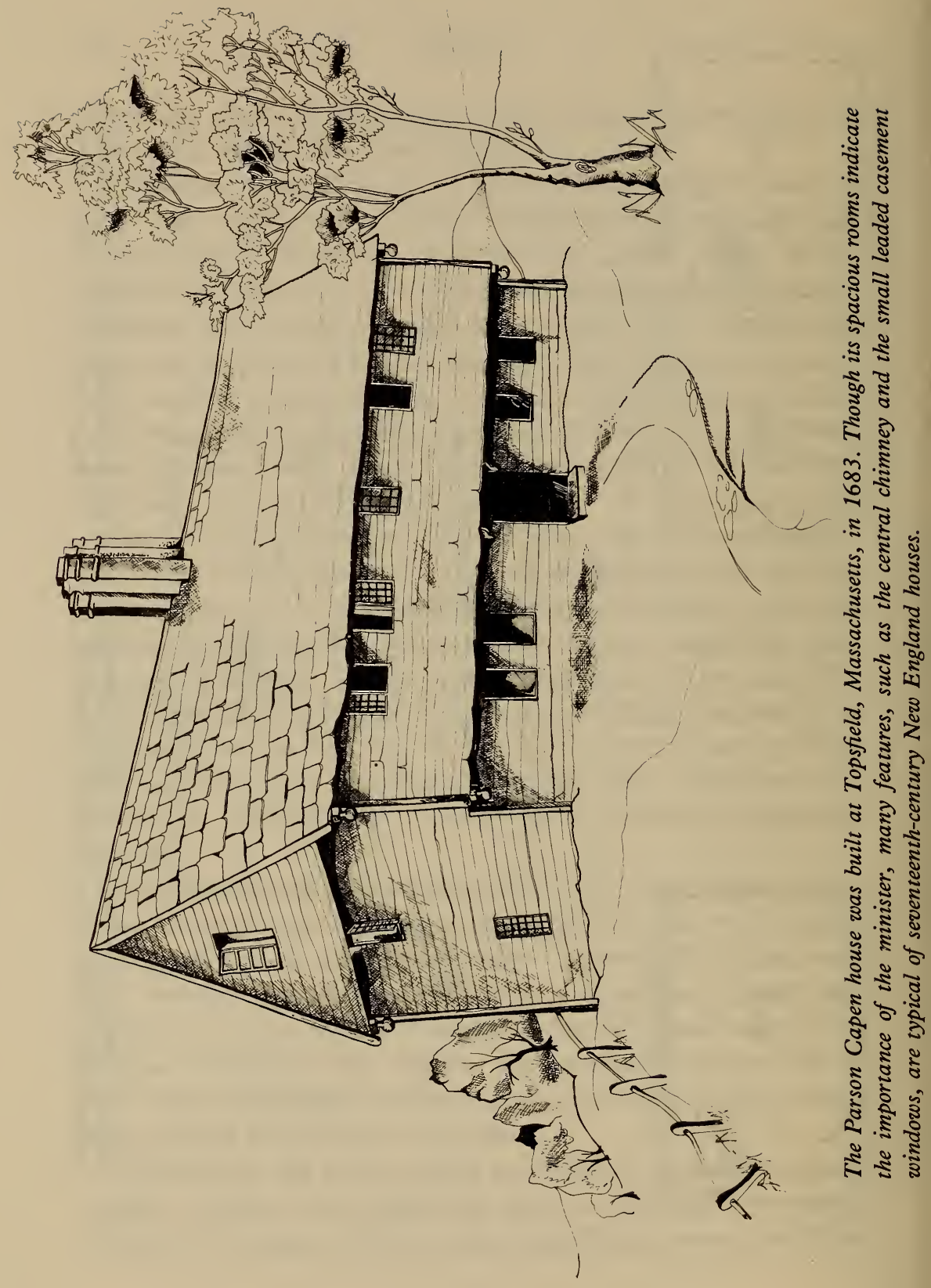


the front door opened onto a small entry-way, or 'porch' as it was then called. Immediately ahead was a staircase built against the side of the immense stone chimney. This led to a sleeping space under the roof. The hall, or main room, took its name from medieval England, and was a combined living, cooking, and dining room. In New England this was sometimes known as the 'keeping room', a term which again came from England, and is linked with the castle keep.

Many poorer families continued to build one-roomed dwellings throughout the seventeenth century. The natural development from this very simple form, however, was the two-roomed house with central chimney. The chimney had two fireplaces back to back, and not only served as a strong pillar at the centre of the building but also provided all-round warmth. The second room became known as the parlour. It was mainly used for special occasions, such as the entertainment of guests, though it might also serve as a bedroom.

A third variant on the basic plan came about with the addition of a single-storey lean-to, covered by roof rafters carrying down from the eaves at the back of the house. The resultant shape caused these houses to be known as 'saltboxes'. The central section of the lean-to was generally used as a kitchen. Another fireplace was added to the chimney on that side, and sometimes a bake-oven too. Space on either side of the kitchen might be used for a pantry and an extra bedroom. By having separate areas for some of the functions of the other rooms, particularly of the hall, the saltbox house provided more comfort than the very simple early buildings. 

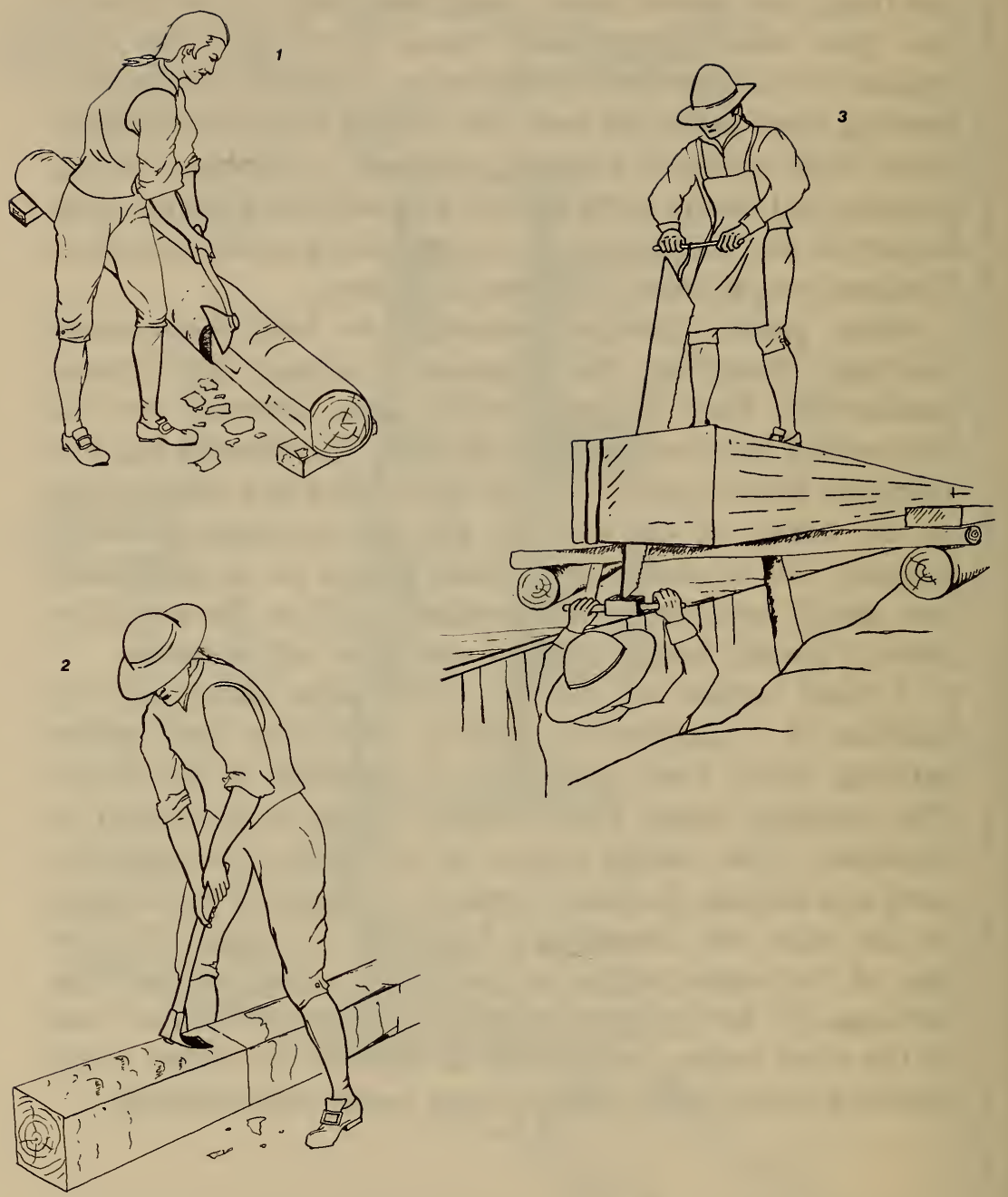

Building tools in use: 1. The broadaxe was used to square off the framing timbers. 2. Exposed timbers were smoothed with an adze. 3. The two-man whip-saw served to cut long planks and boards. 


\section{Inside the Home}

The first thing that would probably strike a modern visitor on entering one of these homes would be the stark simplicity of the rooms. The solid frame of the house was evident in the low beams and in the corner posts. Woodwork was hand-finished and unpainted. The walls were plastered and whitewashed, or partly covered by wainscot, while the floors were of plain wide boards. Dominating the room, whether hall or parlour, was the great fireplace, sometimes eight feet or more in width, with an oven built into one corner of the brickwork. The room would seem dark to the modern visitor, even during the daytime, because of its small windows. Apart from the fire it was lit at night by candle or simple oil lamp. The members of the household rose early to make full use of the precious hours of daylight.

The hall served as the general living room. In the centre was a long table, perhaps with a trestle base and a pine board which could easily be removed after a meal, though by the end of the century folding tables were beginning to be used. The most valued pieces of furniture - a bedstead and chests - stood against the walls. Shortage of space meant that chests were the chief means of storage, particularly for bedding and clothing. They often served as seats. Benches and joined stools were common, together with some chairs, though there were many households which contained only a single chair.

A variety of woods went into the making of this furniture, the main one, as in Jacobean England, being oak. Pine was used for lids and backs, where the stronger wood was not required. Walnut, maple, and ash were also used, particularly 


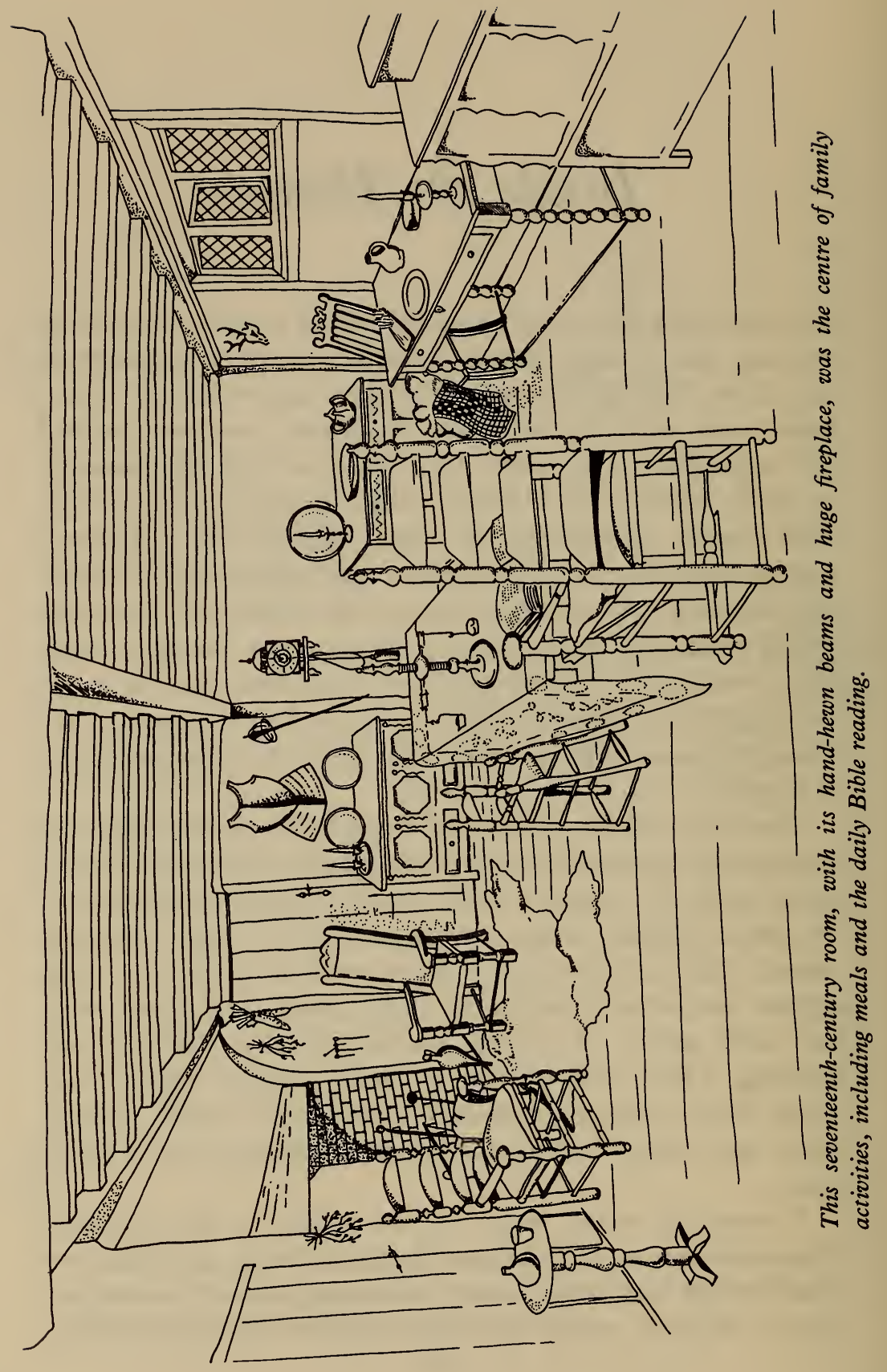




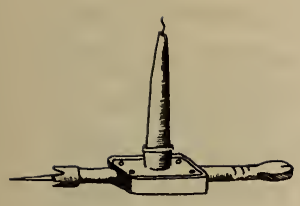

1

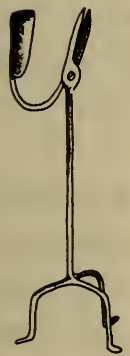

5
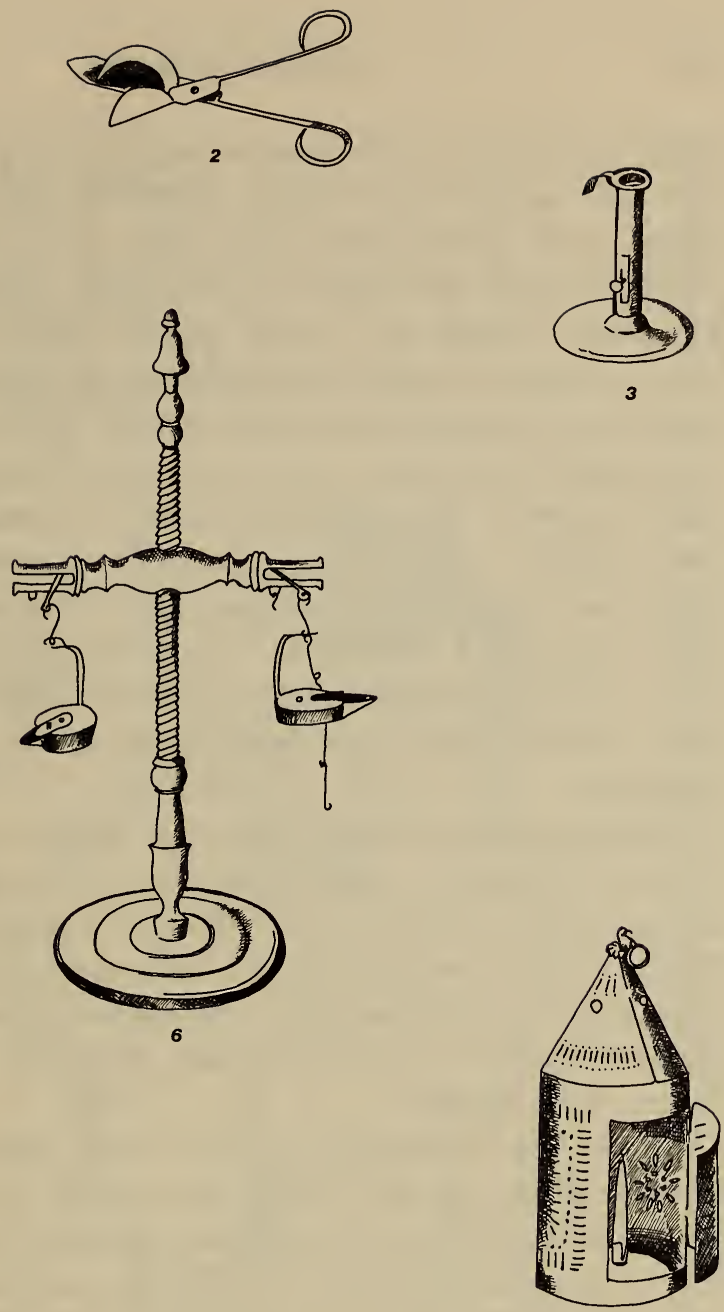

4

Colonial lighting implements: 1. A candle holder mounted on wood, with an end-spike for insertion into a beam. 2. A candle snuffer, used for trimming wicks. 3. A candle stand with a slide to adjust the height as the candle burned. 4. A lantern of pierced tin, with a candle holder inside. 5. A rush-light holder combined with a candle holder. 6. An ingenious wooden betty lamp holder, with a screw post to regulate height; each betty lamp had a wick and burnt oil or grease. 
towards the end of the seventeenth century. In general furniture was made from straight pieces of wood joined at right angles with mortise and tenon. The only rounded elements would be table and chair legs, and chair spindles, which were sometimes turned on a lathe. A good deal of furniture with bold carving or brightly painted patterns, mainly using natural motifs, has survived from that period. Much of it was made by English craftsmen who came to the colonies. Its survival may be due to the skill involved in its manufacture, and the value placed upon it by succeeding generations. Most of the furniture in seventeenth-century New England homes, however, was made by the owner of the house. The hard demands of his life left him little time for decorating his home. Furniture, like the house itself, was simple, if well made, with little ornament.

The plainness of these rooms was offset to some extent by a variety of objects - table linen and cushions for example. An animal skin, of deer or bear, might be found on the hearth, though carpets were rare, and were used as table rather than floor covers at this time. More prosperous homes might include imported items - a lantern clock, delftware, books, and perhaps a looking glass.

By the late seventeenth century many houses had a kitchen separate from the hall. Food was cooked in pots hanging on chains or hooks from the wooden lug pole which bisected the flue of the chimney. Diet was far less varied than today, and consisted chiefly of 'hasty-pudding', made with corn meal and milk; meat and fish when these were available; and vegetables, particularly beans. Much of this food was raised on the farm. Some of it came from the home lot, which also provided apples for the cider which was commonly drunk at most meals. Food was served on either wooden or pewter plates, and was eaten with the help of a knife or spoon, or with the bare hands. Forks 


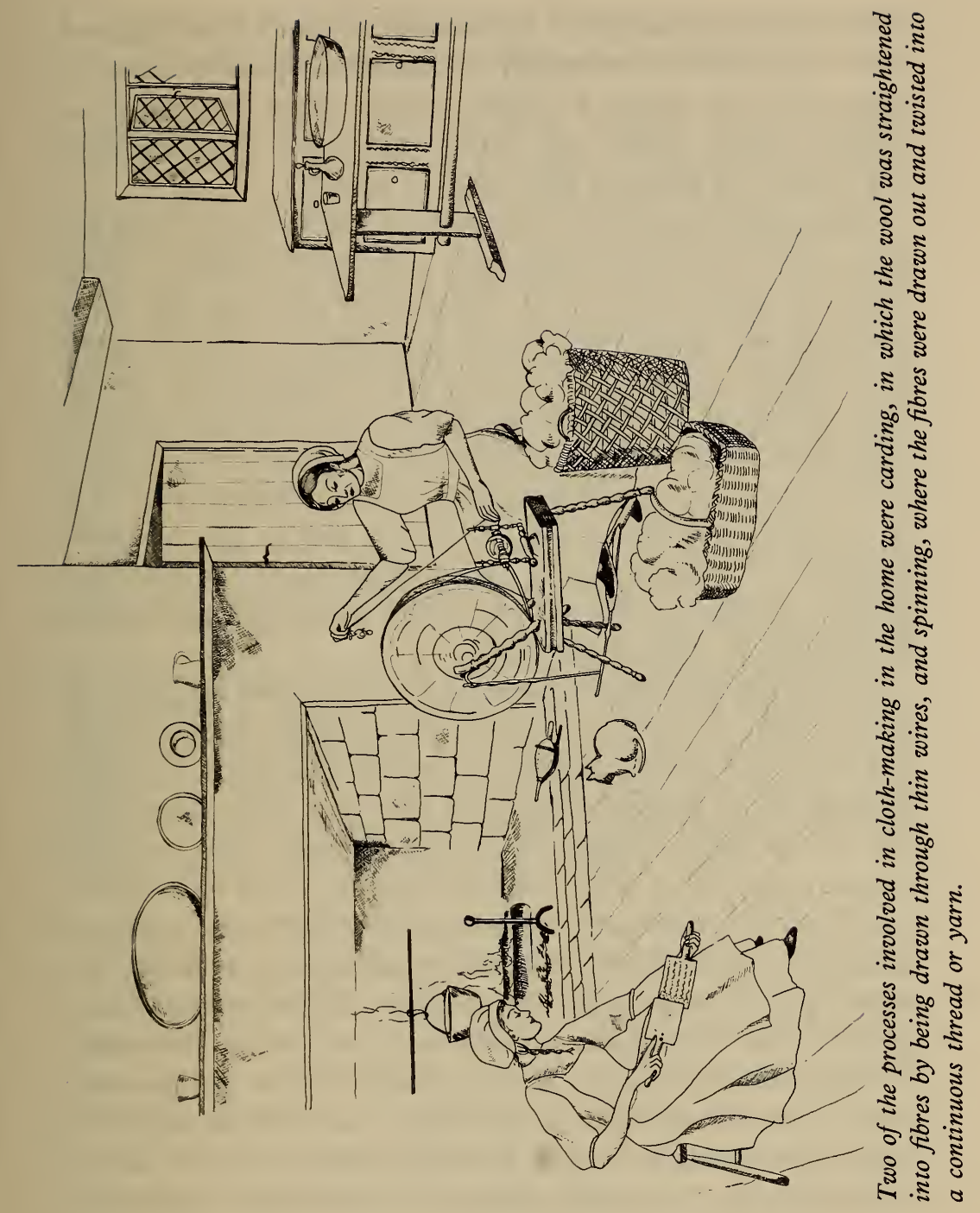


were not in general use in seventeenth-century New England. Even the relative prosperity of Samuel Sewall's house in Boston did not appear to include forks. When the house was burgled Sewall wrote, 'My Spoon and Knife, and Neckcloth was taken.' No mention was made of a fork.

Many other household chores were carried out in the kitchen. One of the most important was candle-making. Tallow from the farm animals was rendered by heating, and when sufficient had been collected was again melted. Into the liquid were dipped strands of cotton wicking hanging from a stick. Some of the tallow stuck to the wicks, and was then allowed to cool before the wicks were dipped again. The process continued until the candles were large enough to use. Another task was to fill a tub with layers of ash and straw, and to pour in small quantities of boiling water. This formed lye at the bottom of the tub, which was then drawn off and mixed with grease from the kitchen to make a soft soap.

One of the greatest problems in the home was the preservation of meat. A brine tub was to be found in most kitchens, and meat was either pickled, or salted and cured on hooks hanging in the fireplace. Later the meat was made more palatable by the use of herbs. The seeds of plants such as fennel and carraway were often used in cooking. Even more important from the housewife's point of view were the medicinal qualities of herbs. Often the only medical help available in a village was the knowledge which some old woman had of these qualities. She would know when and how to use the catnip, the sage, the spearmint, and the host of other plants which grew in the herb garden close to each house. Something of the importance attached to this form of medicine can be seen in the popularity of herbals, and the extraordinary claims they made. One which was sold in seventeenth-century New England had this to say of sage: 
'It stays abortion, it causeth fruitfulness, it is singular good for the brain, it helps stitches and pains in the sides.'

The main occupation in the home, apart from the preparation of food, was the making of textiles. Women of the family had to carry out many processes before the raw wool and flax could be turned into cloth. Wool was cleaned and carded, then spun into yarn on a wheel. The weaving loom was a cumbersome machine, and very often one weaver served the whole village. Flax was ripened and beaten to separate the fibre from the rest of the plant. It was combed or hatcheled, before being spun and woven into linen. Some of these laborious jobs were carried out by children, particularly girls. Boys in turn had their own chores, such as bringing in wood for the fire.

All of these and many more tasks filled the waking hours. When the labours of the day were finally done, the dipped candles and the grease lamps were lit, casting shadows around the group gathered by the fireside. Perhaps the head of the family would read to them from the Bible. Then the cluttered and dingy room would become a refuge from the harshness and the dangers of their daily lives. It was times like these which Samuel Sewall must have had in mind when he made the comparison between heaven and a comfortable home.

'As I lay awake past midnight, in my meditation, I was affected to consider how long ago God had made provision for my comfortable lodging that night ... and that led me to think of heaven the house not made with hands, which God for many thousands of years has been storing with the richest furniture .... and that I had some hopes of being entertained in that magnificent convenient palace, every way fitted and furnished. These thoughts were very refreshing to me.' 


\section{Religion and Education}

During the seventeenth century a great many religious sects existed both in Europe and in the American colonies. In Virginia the Established Church was the official religion, and Anglicans were predominant. Maryland was founded by Catholics, and Pennsylvania by Quakers, though both colonies in their search for settlers welcomed members of other religious groups. In Massachusetts, however, where religious dissent was an important motive for immigration, the Puritans controlled secular as well as religious affairs. Despite their own experiences in England, they were harshly intolerant of other religious sects, especially the Quakers who criticised the authority of the ministers. This intolerance led to the founding of other New England colonies, such as Rhode Island and Connecticut.

In spite of the diversity in forms of religion there was an almost universal concern for spiritual matters. When Anglican ministers of Virginia preached that settlement was God's work, their belief in their own destiny was as sincere as that of the Puritans. Life was continually measured by religious standards. Perhaps the Puritans went further than most in seeing God's hand in many things. When Samuel Sewall's house caught fire one summer's night in 1709, his wife gave the alarm, and Sewall quickly put out the fire. But as his diary indicates, he did not take the credit.

'Thus with great indulgence GOD saved our house and substance.'

Even while he and his wife were determining the earthly cause of the fire, Sewall saw no difficulty in assuming that a higher power was also involved. 


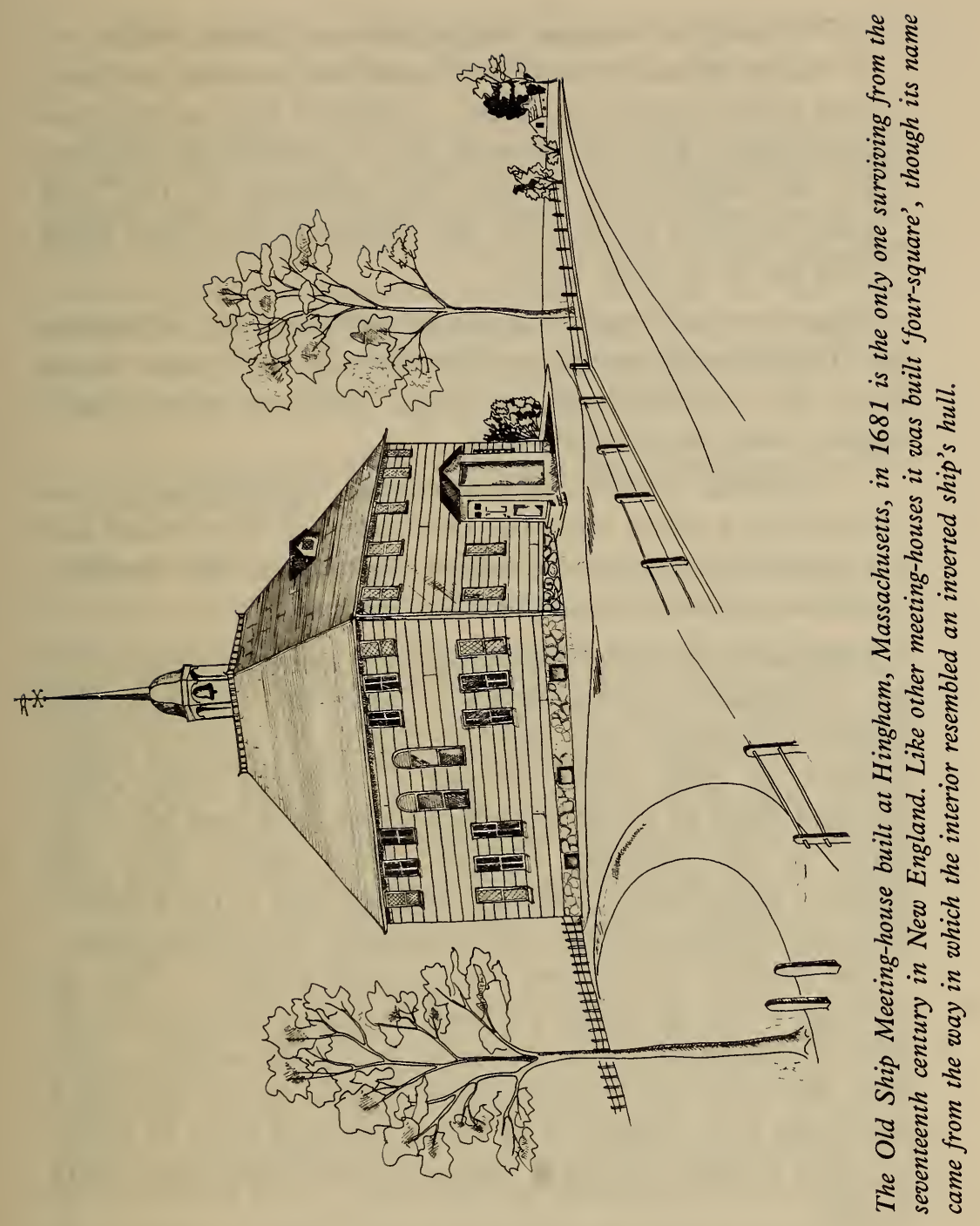


'We imagine a mouse might take our lighted candle out of the candle-stick on the hearth and drag it under my closet door behind the box of wafers.* The good Lord sanctify this threatening; and his parental pity in improving ourselves for the discovery of the fire, and quenching it. The Lord teach me what I know not; and wherein I have done amiss help me to do so no more!'

Observance of the sabbath was an important part of Puritanism. To ignore the teaching of the Bible on this matter was to invite dire consequences, as John Winthrop quite clearly implied when he described how

'Archibald Tomson, of Marblehead, carrying dung to his ground in a canoe upon the Lord's day, in fair weather and still water, it sunk under him in the harbour near the shore and he was never seen after.'

Attendance at church on the sabbath had been enforced by law in England, and the practice was carried over into New England, although the 'church' became a 'meeting-house'. Puritans in each village formed a corporate body which managed many of the affairs which would have been left to the clergy in the Anglican Church. They elected their own minister; called vestry meetings; granted land to the minister; and made arrangements for the building of the meeting-house.

The Puritan 'church' was - as its name implies - a hall for meetings. It was generally a framed building with little decoration. The emphasis was not on ritual, but on the sermon, which often lasted for two or three hours. A great deal of resolution must have been needed to sit in an unheated room in winter for such a length of time. Samuel Sewall once wrote, with feeling:

* Sewall was probably referring here to the small discs of dried paste which were used at that time for sealing letters. 
'This day is so cold that the sacramental bread is frozen pretty hard, and rattles sadly as broken into the plates.'

Since the Bible was regarded by most Protestant sects as the key to salvation it was essential that children should be taught to read. The General Court of Massachusetts Bay insisted that every town should provide some schooling. Boston and other well-established towns had grammar schools for boys and private schools for girls, but some of the smaller settlements could not afford schools. Sudbury, for example, had to wait until 1692 before being able to appoint a

'Writing school master, to teach the children to write and to cost accounts'.

Where schools were not available parents taught children in the home. Hornbooks were often used. A hornbook was a small piece of wood, with a handle, to which was attached a piece of paper with the alphabet and perhaps the Lord's prayer. The paper was protected by a sheet of transparent horn. Learning was mainly by repetition. Later the child moved on to readers, which were nearly always of a pious nature. Few families owned more than a Bible and perhaps a collection of sermons, though other books, mainly of the more practical kind, were available.

The Puritan attempt to create an orderly community based on religion did not always succeed. Human nature inevitably fell short of the high ideals, and there were many disagreements between ministers and other leaders of the community. Puritanism at its worst was a narrow, superstitious faith which could lead to the excesses of the witchcraft trials in Massachusetts and Connecticut. Yet these largely self-sufficient and self-governing towns did survive the dangers and the rigours of the frontier. In no small part was this due to the faith which played such an important role in both family and community life. 


\section{Defence}

Throughout the colonial period Indian attack was an everpresent danger to the outlying settlements. Despite many treaties minor skirmishes were almost continuous, and major wars took place in some part of the colonies every few years. Other European nations, in particular the French in alliance with Indian tribes, were a further source of conflict. Every able-bodied man had not only to defend his home and family, but to do militia service when required.

The Indian threat appears constantly in contemporary journals. Sometimes it is a brief reference, as with Samuel Sewall's cryptic entry,

'More mischief done at the Eastward by the Indians.'

At other times the conflict became much more serious. William Bradford wrote:

'In the fore part of this year, the Pequots fell openly upon the English at Connecticut, in the lower parts of the river, and slew sundry of them, (as they were at work in the fields,) both men and women, to the great terror of the rest; and went away in great pride and triumph, with many high threats.'

This was the beginning of the fierce Pequot War, which was only brought to an end in 1637 by the destruction of the Pequot tribe in the Connecticut Valley. Bradford's diary describes vividly the burning of an Indian village:

'It was conceived they thus destroyed about 400 at this time. It was a fearful sight to see them thus frying in the fire, and the streams of blood quenching the same, and 


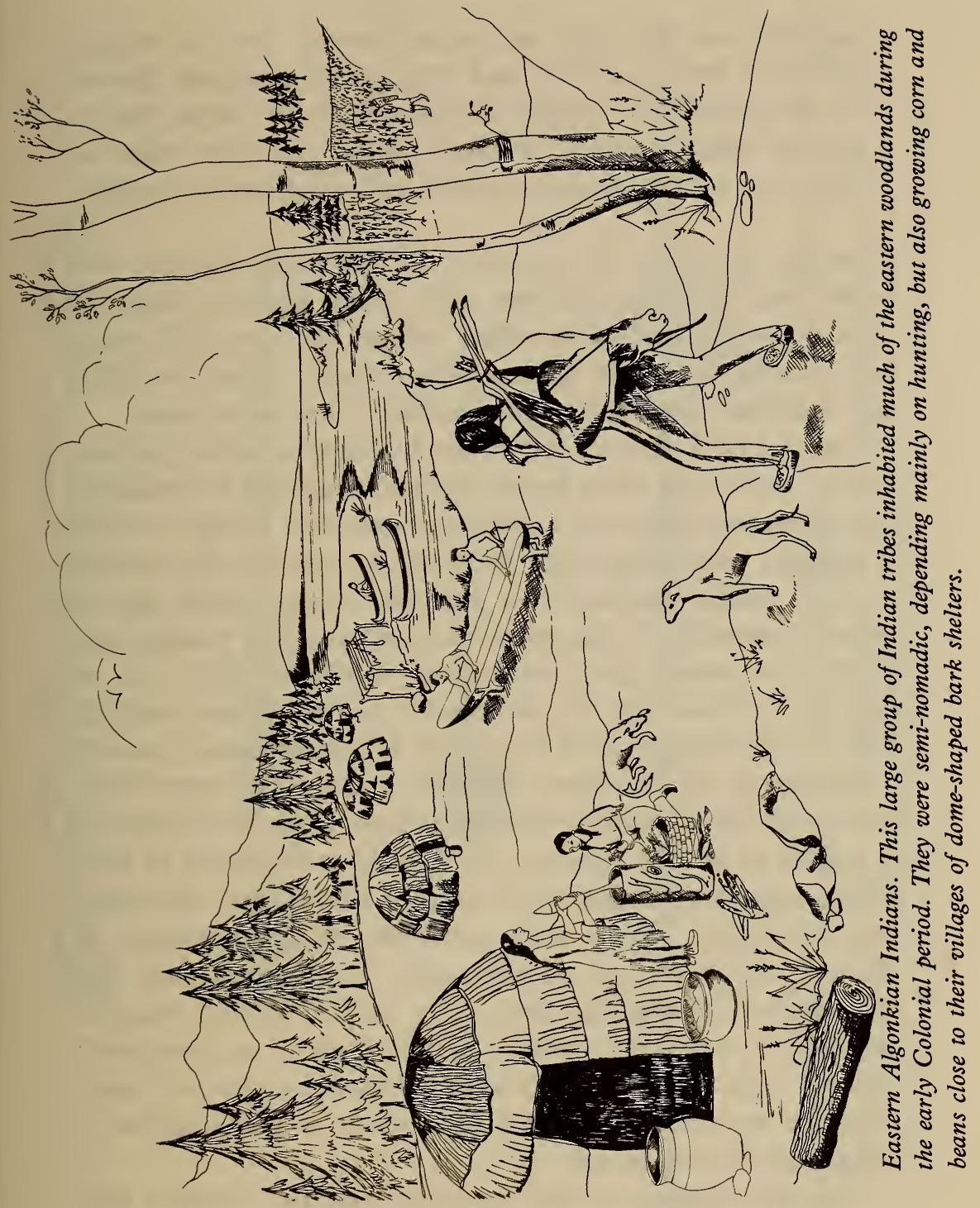


horrible was the stink and scent thereof; but the victory seemed a sweet sacrifice, and they gave the prayers thereof to God, who had wrought so wonderfully for them, thus to enclose their enemies in their hands, and give them so speedy a victory over so proud and insulting an enemy.'

Although Bradford, as governor of Plymouth Colony, had maintained friendly relations with some Indian tribes, his evident satisfaction in this affair reflects the ease with which most Europeans could ignore Indian claims to the land they had inhabited long before the coming of the white man.

The need for defence led to the building of either garrison houses, or in the early period stockades around the villages. The garrison house was a solidly constructed refuge in times of danger, which might last for a day or two, or even months on end. 'Indian summer' is a term used today which had an ominous meaning for the remote settlements. Fine weather late in the year meant that the Indians would be able to go on attacking unhindered by the severe winter. Major conflicts such as the Pequot War led to the first movements towards a federation of the New England colonies for protection. But it was local conflicts which made necessary the setting up of militia in all the villages. The central government in each colony passed laws relating to defence throughout the seventeenth century. These laws concerned the appointment of officers, the provision of arms and ammunition, and the organisation of training days. The militia captain had the authority to take over control of the village in an emergency. In these ways a citizen army was established, armed and maintained in separate settlements, but ready to join together in companies in time of war.

The first settlers in the American colonies brought with them European arms and armour: matchlock muskets and 

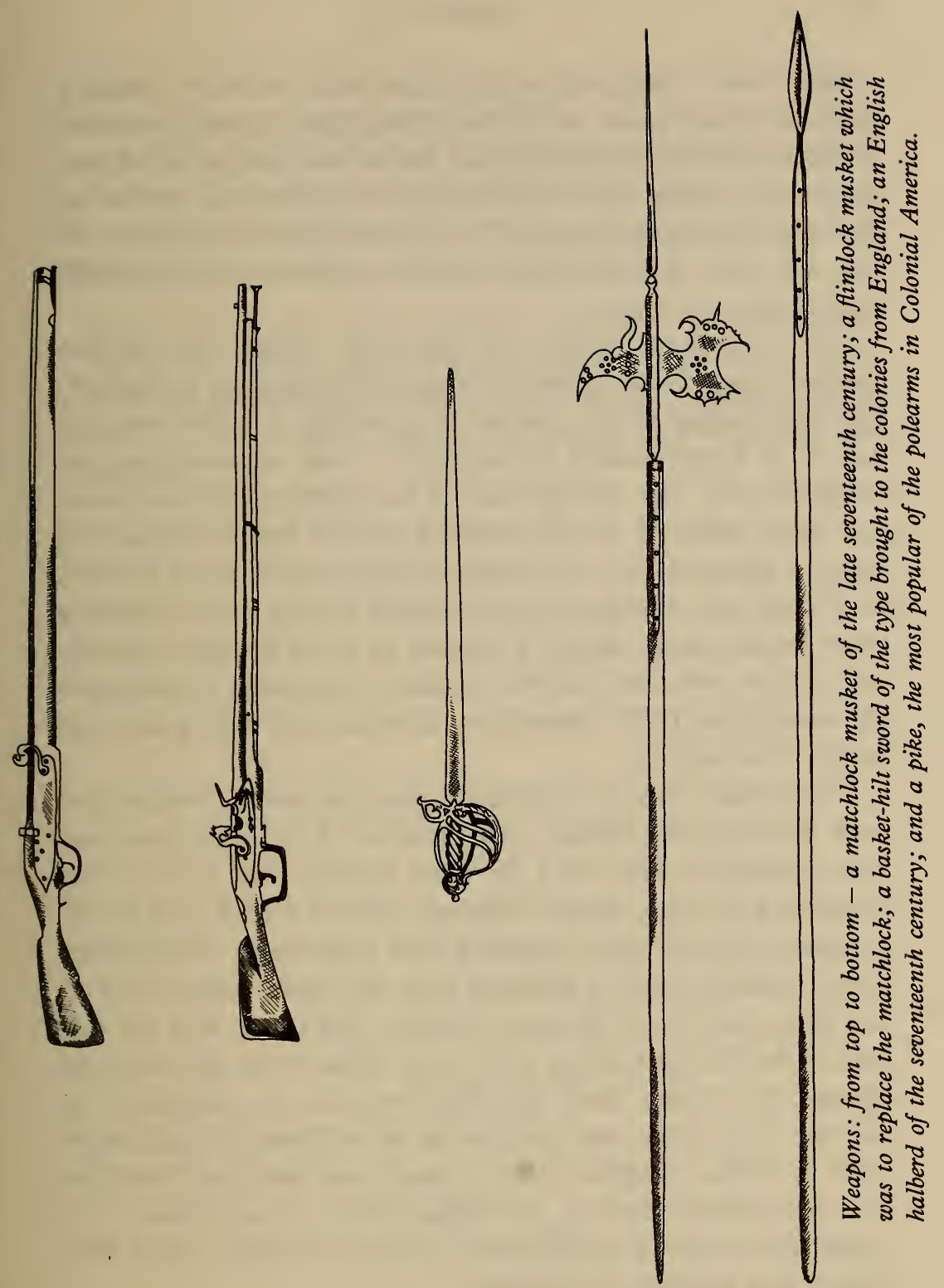
swords were common, while those with military training might also have pikes and halberds, and heavy suits of armour. In the New World, however, they found new conditions of warfare. The Indian did not fight pitched battles, preferring ambush and surprise attack. The forest provided his cover, the bow was silent and accurate, and the tomahawk made a deadly close-quarters weapon.

The matchlock musket of the first settlers had serious disadvantages. Loading was a long and complicated procedure, and the igniting of the powder by a 'match' - a slow-burning strand of hemp soaked in saltpetre - was cumbersome and dangerous. By the second half of the century the matchlock had been replaced by the flintlock, which had a mechanised form of lighting by the striking of flint against a bar of steel. In Europe the change-over took much longer, but in America every frontiersman needed a weapon he could fire more quickly and in any weather. Several colonies, including Connecticut for example in 1676, passed laws allowing only flint guns to be used by the militia.

The firearm was the colonist's most important weapon for both hunting and defence. All firearms of the time, however, were relatively slow, and in close contact the sword complemented the gun. Many different types of sword used in the colonies have survived, showing how common a weapon they were. Various types of polearm have also been found, such as the pike which was the most popular, the lance, and the halberd. Like the matchlock they were found to be less effective against the Indian than they had been on the battlefields of Europe. They often continued in use as emblems of rank rather than as useful weapons. Plate armour was also used until the late seventeenth century, but began from an early date to be replaced by leather coats made of cow or ox hide, which were lighter and cheaper to produce. 
Arms and armour were as much part of the New England home, especially in the country districts, as the spinning wheel or the Bible. Indeed practical and spiritual needs never seemed to be very far apart in seventeenth-century New England. In the articles of federation of 1643, Massachusetts, New Plymouth, Connecticut, and New Haven did

'enter into a firm and perpetual league of friendship and amity, for offence and defence, mutual advice and succour upon all occasions, both for preserving and propagating the truth of the Gospel, and for their own mutual safety and welfare'. 


\section{A New World}

Towards the end of the seventeenth century the influx into the American colonies of immigrants from countries other than England greatly increased. Until that time, however, the vast majority of settlers were of English stock. This was particularly so in New England. Inevitably they brought with them traditions and skills which helped to mould their new way of life. The New England village or 'town' of the seventeenth century was similar in many ways to an English village. Houses were built, for example, not on the land being farmed, but together in some convenient spot by a stream or spring. They fronted the village street, and each had its own outbuildings, garden, and orchard. Beyond the village lay the fields and meadows in which could be found the animals and some of the crops typical of the mixed farming carried on in many parts of England.

There were, however, some notable differences. In England there had been a shortage of timber since Tudor times, and the use of wood as the main building material was confined to certain areas. The dense forests which surrounded most New England settlements provided plenty of wood for buildings of frame construction and weather-beaten boarded exteriors.

A few buildings stood out from the rest: the meeting-house with its open belfry, the solid garrison house, perhaps a schoolhouse, and even a tavern with a crudely painted sign. But there was no manor house, just as there was no church in the sense of a building which represented the Established Anglican Church. The traditional sources of authority in the English village were absent. The Governor and the General Court enacted laws for each colony, but the centres of government 


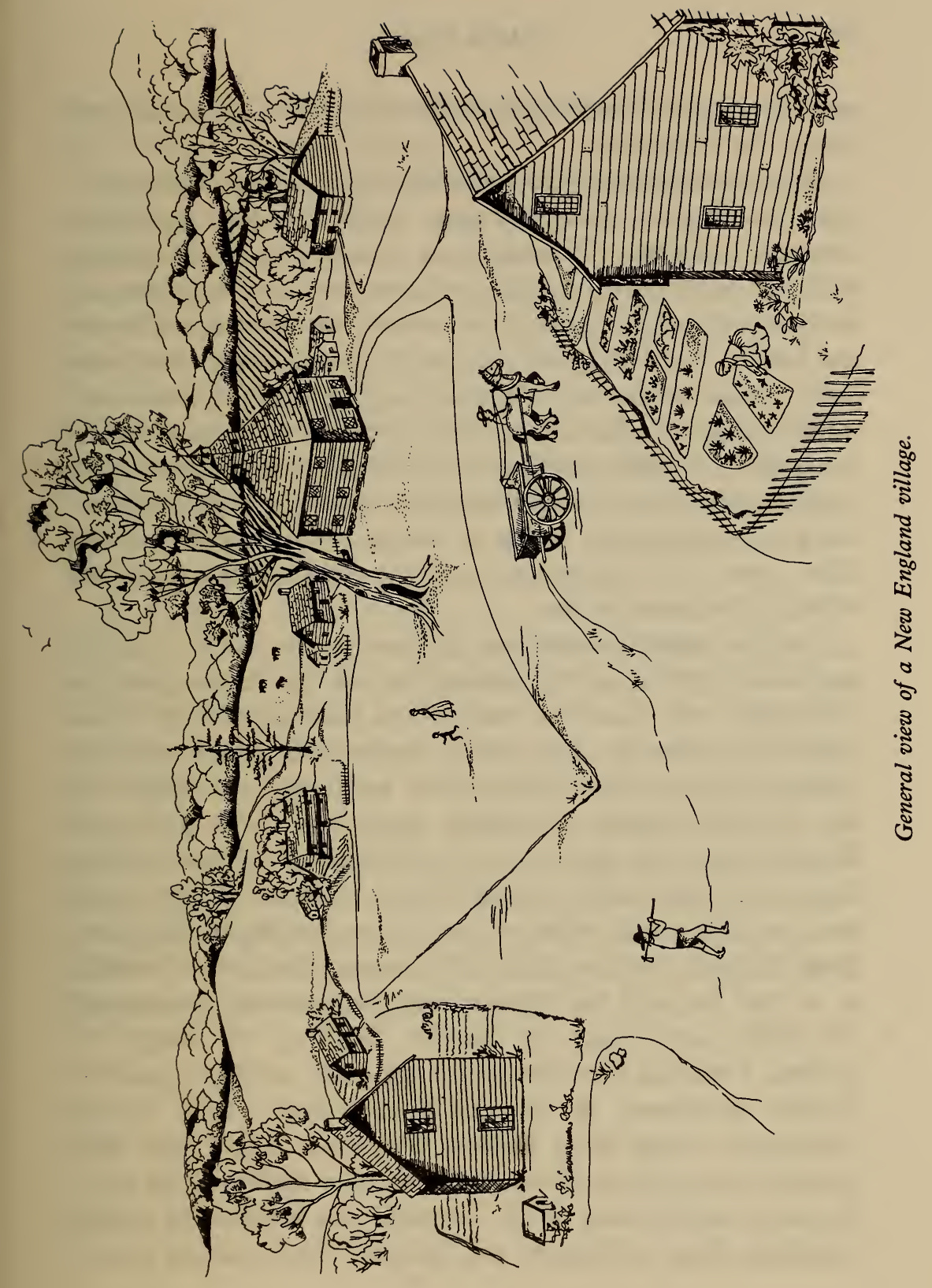


were far removed from most of the settlements, and communication was infrequent.

All resident householders regularly gathered in the meetinghouse to discuss their common needs. Leaders inevitably emerged, to become 'selectmen', or to head committees dealing with particular problems. Most settlers, however, had some say in the town's affairs, whether it was the maintenance of roads and fences, the levying of rates, or the preservation of law and order. As members of a Puritan congregation they also controlled religious affairs, from the appointment of ministers to the censure of other members for offences such as swearing or drunkenness. In the later settlements church membership was not a prerequisite for voting in the town meeting. But in the older towns the congregation and the town meeting consisted of much the same people.

Like the meeting-house the garrison house had no English equivalent. Following the destruction of the Pequot tribe in 1637 there was peace for many years, interrupted only by an occasional skirmish. But always beyond the town and the outlying fields lay the dark forest, reminding the settlers of the possible danger of Indian attack. In June 1675 the Wampanoags rose against the New England colonies. In the fierce guerrilla warfare which followed almost all the towns were attacked, and twelve of them were completely destroyed. King Philip's War, as this conflict was called, was brought to an end through the superior organisation and weapons of the white man. Along the frontier, however, the danger remained. Deerfield was situated at the most northerly point of English settlement in the rich Connecticut Valley. It was abandoned during King Philip's War, later rebuilt, and then attacked several more times. On a winter's night in 1704 came the most terrible blow of all. Deerfield was attacked by a large combined force of French and Indians. Over half the town's 
three hundred inhabitants were either killed, or captured and sent northwards into Canada.

The need to make decisions within the community, together with the hardship of their daily lives, bred a spirit of selfreliance and independence among the New England settlers. So much so that almost two centuries later John Adams, second President of the United States, and himself a New Englander, traced the history of the American Revolution as far back as the period of early settlement. One important reason for the development of this spirit of independence was the vastness of the land which lay before the colonists. Hunters and traders brought back fairy tales of fertile land in the back country which induced many farmers to move away from the older coastal settlements.

On a map of North America the area thus settled by 1700 appears to be a very narrow coastal strip. Yet by that time, and despite the rigours of frontier life, many settlers had moved beyond the fall line of the rivers in the valleys of Connecticut and Massachusetts. They had moved northwards into Maine, as yet part of Massachusetts, and into New Hampshire. This movement gathered momentum with the growing number of immigrants in the next century. As settlements were established a way of life evolved which owed much to English origins, but perhaps even more to the influence of the New World environment. The settlers of New England had begun to create their own New World. 


\section{Suggested Reading}

Of Plymouth Plantation, William Bradford. Edited by Harvey Wish. Capricorn Books, New York.

William Bradford went to Plymouth in 1620 on board the Mayflower. On the death of John Carver, he became governor, and remained in this post for most of his life. His account of its founding and subsequent growth is the basis for all accounts of Plymouth Colony.

The History of New England from 1630 to 1649, John Winthrop. Edited by J. K. Hosmer. Charles Scribner's Sons, New York.

John Winthrop arrived at Salem in 1630, and later became governor of the Massachusetts Bay Colony. He founded Boston, which was the leading town in the colonies during the seventeenth century.

The Diary of Samuel Sewall. Edited by Mark Van Doren. MacyMasius, New York.

Samuel Sewall was taken to Massachusetts from England as a child. In 1683 he was elected to the General Court in Boston. He also served for many years as a judge, eventually becoming Chief Justice in the colony. He was the only judge involved in the Salem witchcraft trials to later publicly recant.

America - The Story of a Free People, Nevins and Commager. Oxford University Press.

Everyday Life in Colonial America, Louis B. Wright. Batsford.

Colonial America, Robert G. Athearn. American Heritage Publishing Co.

The Pilgrim Fathers, W. J. C. Gill. Longman.

Puritan Village, Sumner Chilton Powell. Wesleyan University Press, Connecticut. 
The Northern Colonial Frontier, Douglas Edward Leech. Holt, Rinehart and Winston, New York.

Arms and Armor in Colonial America, Harold L. Peterson. Bramhall House, New York. 
THE AMERICAN MUSEUM IN BRITAIN tells the story of how Americans lived from the seventeenth to the nineteenth centuries through a series of completely furnished rooms with original panelling brought from the United States and installed in Claverton Manor. Contrasts in the life of colonial New England are shown in the Puritan Keeping Room of the 1680's and the cosy tavern kitchen of the 1770's with its beehive oven and well-protected bar, in the blue-green panelled living room from Lee, New Hampshire, and the mid-eighteenth century parlour of Captain Perley who led his Minute Men at the battle of Bunker Hill. The sophistication of the parlours from Colchester, Connecticut, and Baltimore, Maryland, introduces the period of the new Republic. An early nineteenth-century country-style bedroom contrasts with the elegance of the Greek Revival dining room of New York and the richly ornate bedroom from New Orleans at the time of the Civil War.

In addition there are galleries devoted to the American Indian, the Pennsylvania Dutch, the religious community of the Shakers, and the isolated Spanish colonists of New Mexico. There are further exhibits on the Opening of the West, whaling (with a captain's cabin reproduced from the last of the great Yankee whalers), textiles (with a fine collection of quilts and hooked rugs), pewter, glass, and silver. In the attractive grounds is the semi-circular gallery displaying the vigorous forms and primitive designs of American Folk Art. There is also an 1830 Conestoga wagon, the observation platform of a railroad car, and a replica of a Cheyenne tepee. 
Public opening: April to mid-October, daily (Mondays excepted), 2 pm$5 \mathrm{pm}$.

The Museum is open to schools throughout the year (January excepted) at the following times:

Mid-October to March Monday to Friday

April to mid-October Mondays

Tuesday to Friday Mornings only
9.30 a.m. -12.30 p.m. 2.00 p.m. -5.00 p.m.

As above

The John Judkyn Memorial, Freshford Manor, Bath, is associated with the Museum and provides a loan service of material relating to American history and culture. Some loan kits can be seen at the Museum, and information on borrowing is provided.

All enquiries concerning these educational services should be made to:

The Education Department,

The American Museum in Britain,

Claverton Manor,

Bath.

Tel.: Bath 60503.

Printed in Great Britain by Butler \& Tanner Ltd, Frome and London 


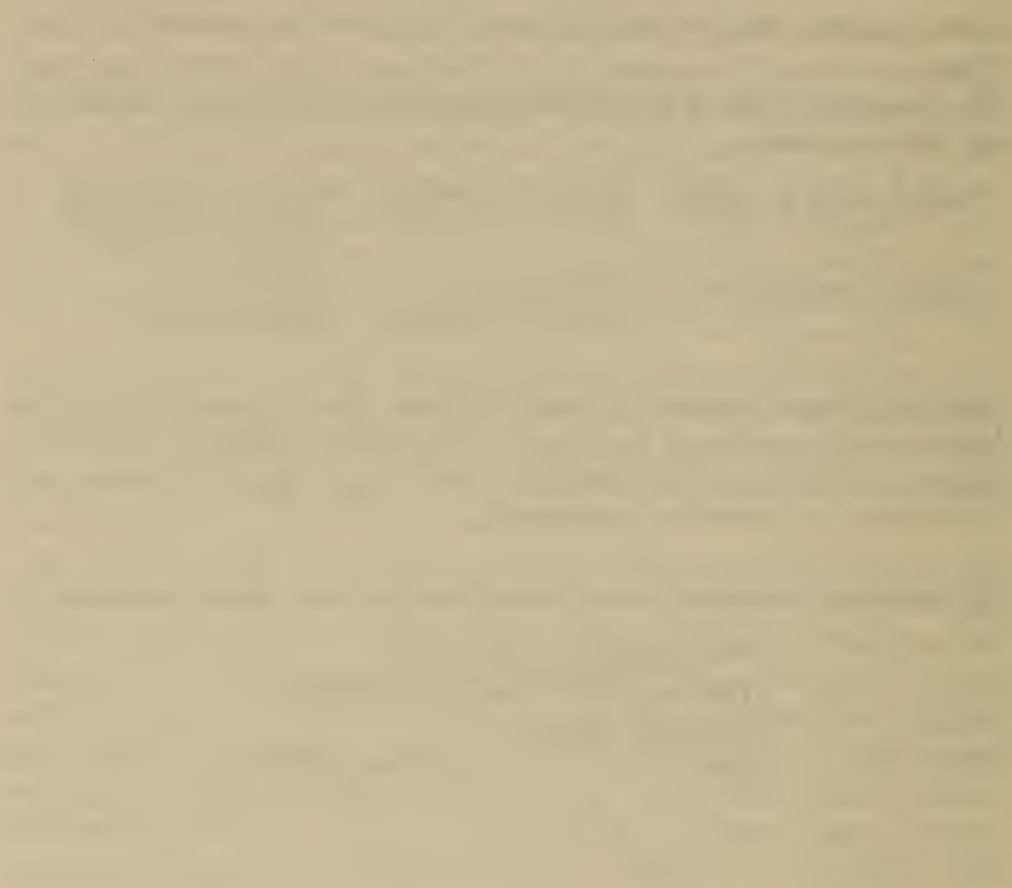




\section{SMITHSONIAN INSTITUTION LIBRARIES \\ 3 9088 00298480 5 \\ Newg F7.C218}

New England village : 